Article

\title{
Indicators for Sustainable Demand Risk Allocation in Transport Infrastructure Projects
}

\author{
Athena Roumboutsos ${ }^{1, *(\mathbb{D})}$, Alenka Temeljotov-Salaj ${ }^{2, * \mathbb{C}}$ and Iosif Karousos ${ }^{1}$ \\ 1 Department of Shipping, Trade and Transport, University of the Aegean, 82100 Chios, Greece; sifi@aegean.gr \\ 2 Department of Civil and Environmental Engineering, Norwegian University of Science and Technology, \\ 4791 Trondheim, Norway \\ * Correspondence: athena@aegean.gr (A.R.); alenka.temeljotov-salaj@ntnu.no (A.T.-S.); \\ Tel.: +47-46445072 (A.T.-S.)
}

Received: 28 October 2020; Accepted: 17 November 2020; Published: 19 November 2020

\begin{abstract}
Efficient risk allocation has been proven to be at the heart of effective and efficient infrastructure project operation. While most risks may be reasonably assigned in transport infrastructure projects, demand risk remains ambiguous due to the multiple factors influencing its appropriate allocation. The present research is a first attempt to introduce indicators as tools to guide contracting parties in assigning demand risk. The level of control, based on infrastructure characteristics and attributes, describes the potential control over demand an operator may have. The optimal demand risk allocation is seen as an assessment of the appropriateness of demand risk allocation effected. The indicators are constructed following accomplished rules set by supranational organizations. Furthermore, 51 project cases ranging different transport infrastructure modes from 19 European countries including projects delivered traditionally and as Public Private Partnerships were used to validate the indicators and assess their performance. Results show the potential of both indicators to guide governments, operators and also financiers in appropriately allocating demand risk in transport infrastructure projects. This optimality was shown to be related to more accurate traffic forecasts resulting in sustainable transport infrastructure as the project then delivers on its economic, environmental, and social/welfare targets.
\end{abstract}

Keywords: transport infrastructure; sustainable demand risk allocation; Public Private Partnerships; composite indicators

\section{Introduction}

Thriving for sustainable infrastructure projects, especially in the transport sector, concerns balancing public and private investments so as to maximize output in terms of providing infrastructure that will meet future demand as per capacity, technology and innovation, social needs, and, recently, resilience to climate change. Traffic demand and other infrastructure-related returns need to be able to support payback and funding schedules and bear minimum impact on the public purse. Notably, transport infrastructure status has significant impact on economic development and growth while superior results can be achieved when decision and policymakers promote opportunity and Musgravian indicators [1]. Kivila et al. [2] discuss the benefits of intensive and collaborative planning for projects' deliverables and enabling innovative and sustainable practices in the projects.

Given the complexity, size and lifecycle of transport infrastructure projects, there is a wide range of potential risks affecting expected performance [3], despite the potential of capitalizing on the opportunities that risk can present by delivering projects in a cost-effective manner, on time, budget, target, competitively, safely, ethically and sustainably, at a fair profit for all [4] (p. 112). In addition, social welfare is assumed to be achieved through the trade-off between the cost of risk 
bearing and incentives of technical efficiency [5]. This applies to both infrastructures delivered through traditional public funding and various other forms including private financing such as Public Private Partnerships (PPPs). The latter are expected to be more efficient due to the anticipated private sector management skills and the fact that private finance is at risk [6] (p. 163).

\subsection{The Significance of Risk Allocation and Demand Risk}

Equitable risk allocation is considered important when undertaking any project. The objective is to develop a contractual arrangement whereby the cost of risks is at a minimum, achieving overall risk efficiency [7]. Consequently, risk allocation remains an integral part of any contractual setup, and given its critical importance, particularly in PPP projects, numerous studies have been conducted to examine how to achieve efficient risk allocation [8]. Of course, for some risks, efficient allocation is apparent as only one party has the relevant skills and knowledge to manage and contain those risks. For example, construction risk in all delivery models (traditional and PPP-type ones) is allocated to the private sector - the builder. Other risks, such as traffic demand, are more difficult to assign [9] and in practice introduce the question of "how much private sector in the delivery of the specific infrastructure is sustainable?" The Global Infrastructure Hub [10], with the exception of ports where demand risk is reasonably allocated to the private sector, highlights demand risk allocation as ambiguous for all transport infrastructure modes considered (roads, airports, light rail, and heavy rail), while all other risks are presented deterministically in the 2019 edition of the risk allocation tool.

Notably, the significance of demand risk has been acknowledged by many researchers. For example, Grimsey and Lewis [11] identified nine (categories of) risks, which apply to all infrastructure projects. Revenue risks, related to risks in demand, willingness to pay for services etc., feature as particularly crucial; the others being technical risk, construction risk, operating risk, financial risks, force majeure risk, regulatory/political risks, environmental risks, project default resulting from a combination of risks (p. 189). "Low traffic demand" featured as the most often mentioned downside risk in PPP transport projects [12]. "Insufficient revenue in the market", in other words "demand or revenue risk", was identified as one of the key risks in the group of highly vulnerable and easily influenced risks that may trigger negative reactions leading to contract risks [13]. However, as Gossling [14] mentioned when studying air transport futures, it is not about the "possibility, framed economically, by a limited number of actors, the proponents of volume growth, and less in terms of plausibility or desirability". It is about alternative pathways, risks and vulnerabilities weighed against short-term benefits that can only be achieved with managerial control over the risk.

\subsection{Allocating and Addressing Demand Risk}

Loosemore et al. [15] propose that the allocation of risks should follow established rules. First, the party undertaking a risk should be fully aware of the specific risk and have a greater capacity to manage the risk effectively and efficiently. Then, it should be the party with the capacity and resources to cope with the risk eventuating. Finally, the party undertaking the risk should have the will and possibility to charge the respective risk premium. In other words, the authors emphasize the importance of "control" over a risk and its allocation to the party who can best exercise it.

Many infrastructures inherently provide "control" to their owner/operator. Transport infrastructure bears characteristics of a natural monopoly, which, in the case of a PPP arrangement, is regulated upfront through the PPP contract [16]. Despite this, the benefits of "ownership" are affected by the planning of other new or upgraded transport infrastructure/services, as the boundaries of the "project owner" are often blurred [17]. In many cases, in order to "protect" the private parties' "monopoly status", specific terms are built into PPP contracts protecting the asset from "competitive" infrastructure, i.e., against the public sector developing other transport infrastructure, which may reduce the "level of monopoly status" or what is termed herein "level of exclusivity" (LoE). The LoE may be enhanced or threatened by the quality of transport network integration. Transport integration is an objective of transport policy, but transport infrastructure projects are delivered in a fragmented manner through 
independent traditional and PPP contracts and operated by independent transport operators. In this context, integration is not always achieved or desirable, as from an operator's perspective, "avoidance of integration" is a strategy to restrict or minimize competition and support the LoE [18-20].

Apart from identifying the attractiveness of the project infrastructure due to its position in the transport network and the quality of effective integration, and thus its impact on the $L o E$ in terms of the ability to exercise control, it is important to consider the scope of the asset with respect to servicing or developing demand for transport services/traffic. More specifically, certain infrastructure assets are provided to serve traffic with limited ability to influence the generation of additional traffic, as this depends highly on the economic activity of the origin and destination they serve. For example, road or urban transit operators may improve quality and offer an attractive pricing/tariff policy but cannot generate or increase traffic demand beyond the influence these measures can provide. Furthermore, the aforementioned flexibilities might not even be contractually available, aggravating the issue [21].

On the contrary, port terminal operators may be considered business developers, as the level of traffic demand generated also depends on their ability to influence respective supply chains [22]. Airport revenues are aeronautical and non-aeronautical (e.g., shops, restaurants, parking, hotels, warehouses etc.). The latter depend on passenger flows as well as on the operators' efforts and diligence [23].

Rajaa et al. [24] investigated demand risk factors in PPP infrastructure projects. They organised risk factors in clusters also including concepts of "control", "exclusivity" and "business": users characteristics (users' wealth, public acceptance, paying experience, facilities management involvement, willingness to pay); facility characteristics (quality of service, level of fee, alternative facilities' fee, level of public benefit delivered by the facility, project location/environmental issues, availability of supportive facilities, infrastructure market access rules and competition); and area characteristics (employment, population and GDP). Their assessed importance depended on the stakeholder resulting in significant differences. For example, while the public sector was found to be comfortable with pricing demand risk, senior debt financiers were not, especially for PPP toll roads [25]. In support of project bankability and in order to attract financial investors, the European PPP Expertise Centre (EPEC) [26] favoured state guarantees to cover a range of risks, which does not necessarily lead to risk efficiency, especially when considering demand risks.

Taking a rational approach [15], Roumboutsos and Pantelias [27] analysed demand risk allocation in 24 transport PPP cases, finding that, in general, the typical rules for risk allocation were not followed. Revenue and remuneration schemes were applied that did not always conform with "the level of control" introducing or mitigating risk. Moreover, the provision of state guarantees, and other risk mitigation measures, price, and revenue caps etc., distorted the control an operator may have over demand risk. Typically, governments introduce risk mitigation measures in order to secure private finance but, by doing so, compromise the potential of the public sector to secure value-for-money. Identifying "control" or how demand risk factors are controlled is important. These credit enhancement tools are considered as standard and include availability-based remuneration schemes, minimum revenue guarantees or grants and payments [28] and are often proposed as a sustainable approach to PPP contract management [29]. Furthermore, identifying the measure of support provided by the state has been more of an art [30] and a focus of research seeking to minimize moral hazard, as there is significant asymmetry in information between the private operator and the public administrator [31-33].

Finally, the ability of the risk bearer to exercise "control" becomes all the more important under extreme conditions, when the delivery model and transportation system needs to demonstrate resilience. Such is the case of extreme weather events manifesting climate change, global economic crisis and, also, the recent COVID-19 pandemic. Most importantly, under extreme events, governments need to direct funds towards social needs with little if any potential for immediate returns [34]. Consequently, infrastructure delivery performance needs to be maximized through risk allocative efficiency, which provides further project opportunities.

As already demonstrated, risk allocative efficiency with respect to demand risk is complex and, clearly, governments need to favour contractual arrangements for the delivery of transport 
infrastructure that match "control" with the allocation of demand risk in order to achieve sustainable delivery and infrastructure performance. In other words, a more sustainable approach to demand risk management, which means introducing tools that may be widely understood and applied.

To this end, the present research proposes the introduction of two composite indicators. The first, "the level of control", (LoC) describes the control an operator may have over demand risk due to the characteristics and attributes of the infrastructure in the transport network. This indicator may guide transport infrastructure contracting and delivery. The second indicator proposed is the "optimal demand risk allocation" (ODA) to be used in the assessment of sustainability. As described in the next section, indicators are a useful tool for decision makers when addressing complex systems such as transport infrastructure projects. These indicators are constructed and then assessed and validated against 51 transport project cases. The analysis also concludes with findings as per the performance of the projects in the dataset benchmarked against optimal demand risk allocation.

\section{Materials and Methods}

The present research focuses on assessing the match between "control" and "demand risk allocation" in the form of a composite indicator and compares it to transport infrastructure performance leading to valuable conclusions and lessons learned. Moreover, this assessment demonstrates that efficient risk allocation results in improved performance and, consequently, in a sustainable infrastructure with public funds and private resources efficiently and effectively used.

\subsection{Materials}

The analysis is based on 51 transport infrastructure projects analysed during the course of the BENEFIT Horizon 2020 project, covering all infrastructure modes from 19 European countries. Cases comprise the collection of case studies initiated by COST Action TU1001 [35,36], the Omega Centre [37] and the BENEFIT project [38]. The cases have been reported using a data collection protocol, which is comparable for PPP and public delivery projects and includes both a description and a qualitative scoring system. Relevant case description variables and their scoring system are presented in Table 1 clustered under three headings: infrastructure characteristics; contractual arrangement; and performance proxies. These variables are used to describe infrastructure projects delivered through PPPs or traditional procurement. Case study information was updated to 2016 and therefore, actual traffic relates to a period following the global financial crisis.

Table 1. Case description variables and scoring.

\begin{tabular}{lll}
\hline & Variable & Description \\
\hline F.1 & Infrastructure Characteristics (I) \\
\hline F.2 & $\begin{array}{l}\text { Business developer vs } \\
\text { Business Servicer }\end{array}$ & $\begin{array}{l}{[\mathrm{F} .1=1=\text { Business Servicer, F.1 }=6=\text { Business }} \\
\text { Developer }]\end{array}$ \\
\hline F.3 & Impact of integration & $\begin{array}{l}{[\mathrm{F} .2=1=\text { in competition with other infrastructure }} \\
\text { options, F.2 }=6=\text { unique/temporary monopoly in } \\
\text { the infrastructure network }]\end{array}$ \\
\hline
\end{tabular}


Table 1. Cont.

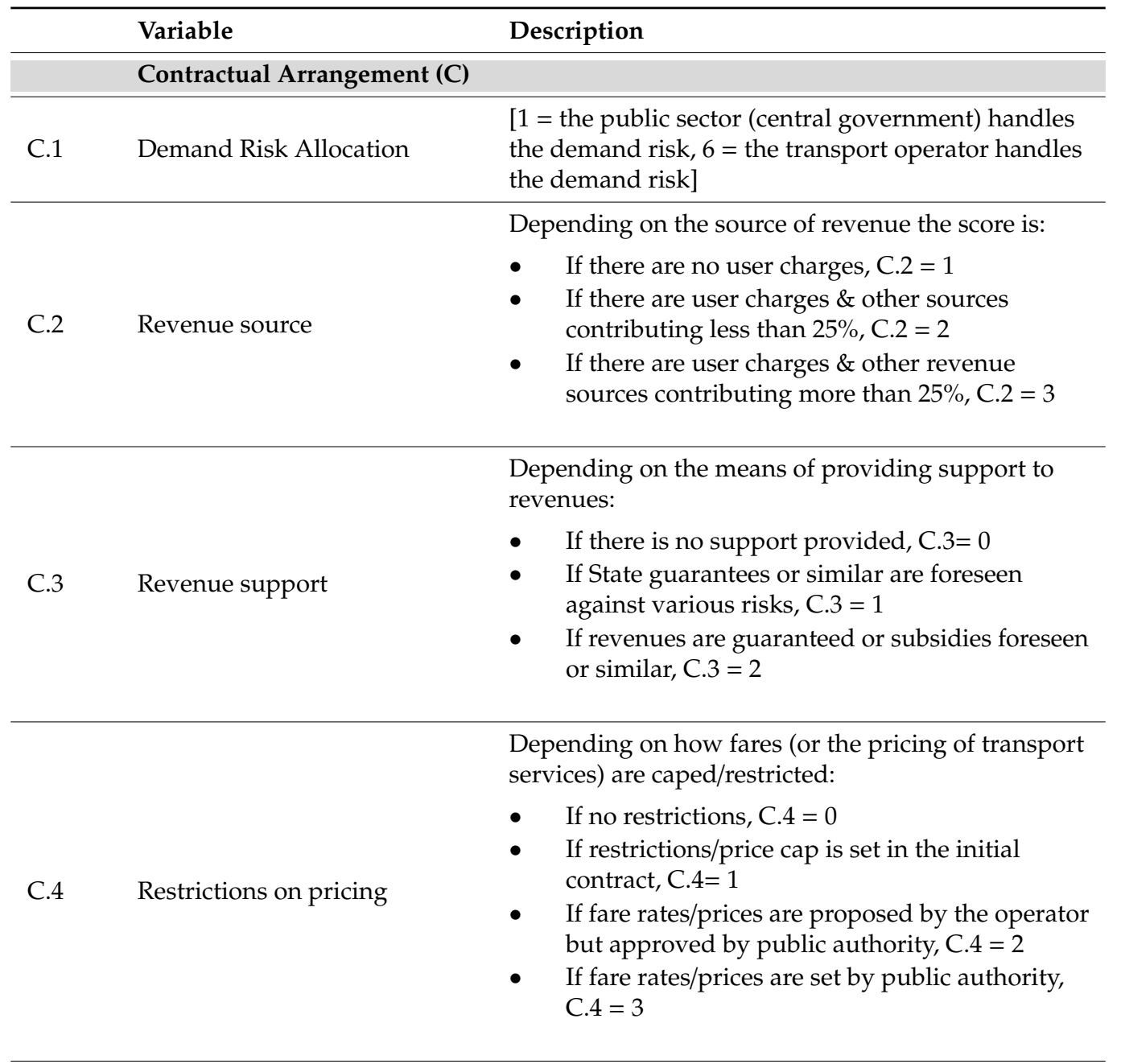

Depending on the source of the remuneration scheme:

- If there are no user charges, C. $5=1$

C.5 Remuneration scheme

- If there are user charges \& other sources contributing less than $25 \%$, C. $5=2$

- If there are user charges \& other revenue sources contributing more than $25 \%$, C. $5=3$

C.6 Incentives Yes $=1 ;$ No $=0$


Table 1. Cont.

\begin{tabular}{|c|c|c|}
\hline & Variable & Description \\
\hline & \multicolumn{2}{|l|}{ Performance Proxies (P) } \\
\hline P.1 & Actual vs forecasted traffic & $\begin{array}{l}\text { An indicator is assigned depending on the level of } \\
\text { achieving forecast traffic: } \\
\text { - } \quad \text { Exceeding forecast, P. } 1=1 ; \\
\text { - } \quad \text { In line with forecast, P. } 1=0 ; \\
\text { - } \quad \text { Below Forecast, P. } 1=-1 ; \\
\text { - } \quad \text { Far below forecast, P. } 1=-2\end{array}$ \\
\hline P.2 & $\begin{array}{l}\text { Actual vs Budgeted } \\
\text { Construction Cost }\end{array}$ & $\begin{array}{l}\text { An indicator is assigned depending on the level of } \\
\text { achieving budgeted cost: } \\
\text { - } \quad \text { Below budget, P. } 2=1 \text {; } \\
\text { - } \quad \text { In line with budget, P. } 2=0 \text {; } \\
\text { - } \quad \text { Above budget, P. } 2=-1 \text {; } \\
\text { - } \quad \text { Far above budget, P. } 2=-2\end{array}$ \\
\hline P.3 & $\begin{array}{l}\text { Actual vs Scheduled } \\
\text { Construction Time }\end{array}$ & $\begin{array}{l}\text { An indicator is assigned depending on the level of } \\
\text { achieving construction schedule: } \\
\text { - } \quad \text { Ahead of schedule, P. } 3=1 \text {; } \\
\text { - } \quad \text { In line with schedule, P. } 3=0 \text {; } \\
\text { - } \quad \text { Behind schedule, P. } 3=-1 \text {; } \\
\text { - } \quad \text { Far behind schedule, P. } 3=-2\end{array}$ \\
\hline P.4 & Macroeconomic (GDP) & $\begin{array}{l}\text { It refers to the macroeconomic indicator compared to } \\
\text { the ones assumed in the planning phase }\left(\mathrm{GDP}_{\mathrm{PP}}\right) \text {. } \\
\text { The variable scores: } \\
\begin{array}{l}\text { - } \mathrm{P} .4=1 \text {, when GDP }>\mathrm{GDP}_{\mathrm{PP}} \\
\text { - } \quad \mathrm{P} .4=0 \text {, when GDP }=\mathrm{GDP}_{\mathrm{PP}} \\
\text { - } \quad \mathrm{P} .4=-1 \text {, when GDP }<\mathrm{GDP} P \mathrm{PP}\end{array}\end{array}$ \\
\hline P.5 & Renegotiations & Number of relevant renegotiations \\
\hline
\end{tabular}

\subsubsection{Infrastructure Characteristics' Variables}

The variables described concern factors important in estimating the level of control an operator has over traffic demand risk. These include:

- The scope of the project and whether its purpose is to serve traffic $(\mathrm{F} .1=1)$, as in the case of roads, or develop business $(\mathrm{F} .1=6)$ as in the case of airports. Obviously, between the two extremes there are intermediate conditions, as for example there are cases of motorways with real estate development and also cases of airports with no non-aeronautical activity.

- The level of exclusivity $(L o E)$ assesses the "monopoly" status of the infrastructure project in the network, ranging from totally exclusive $(\mathrm{F} .2=6)$, as in the case of a sole international airport in a country, to a totally competitive operation $(\mathrm{F} .2=1)$, as for example a tramway in a city with multiple transit alternatives.

- The impact the network integration has on the $L o E$ is also considered. In some cases, integration in the network enhances the level of exclusivity, for example a well-connected international airport $(\mathrm{F} .3=+3)$. In other cases, network integration reduces the level of exclusivity, as in the case of multiple airports serving a particular region $(\mathrm{F} \cdot 3=-3)$. 


\subsubsection{Contractual Arrangement Factors (Variables)}

The key contractual arrangement variable concerned is demand risk allocation. Its value ranges from "allocated totally to the public sector" $(C .1=1)$ to "allocated totally to the operator" $(C .1=6)$. The notion of demand risk allocation, as well as other operational risks, in PPP contracts is common, as the terms of operation are described for the private operator in the respective contract. A similar approach is considered in this research with respect to traditionally delivered infrastructure with demand risk allocation treated in a similar way by considering the central government and the public arm's-length operator who is responsible and accountable for the operation and maintenance of the infrastructure.

Further to the allocation of demand risk, the contractual arrangement includes clauses, as described herewith, that influence positively or negatively the actual risk allocation through mitigation or risk minimization measures. These include:

- The revenue source, with user charges increasing the probability of demand risk eventuating since it relates to user "willingness to pay".

- Revenue support, which rates mechanisms introduced to cap the impact of demand risk such as minimum revenue guarantees.

- Restrictions in pricing of services, which limit the operator's managerial and operational strategies.

- The remuneration scheme, which does not always coincide with the revenue source.

- Incentives, which are meant to drive managerial excellence.

\subsubsection{Performance Proxies}

Three variables are used as infrastructure performance proxies: actual versus forecasted traffic; actual versus budgeted cost to construction completion; and actual versus time to construction completion. In addition, two proxies are used as control variables: the occurrence of contractual renegotiations and macroeconomic growth comparing GDP to that assumed during planning. Notably, while cost to completion and time to completion are unique and correspond to the construction completion date, forecast traffic is related to time. As traffic builds over time, especially in greenfield projects, a better assessment of the achievement of this project goal can be made a few years after the project's inauguration. The later possible date was considered in all cases (2016).

The variable "renegotiations" is a count of renegotiations that took place related to or triggered by revenue or remuneration issues as there could be numerous factors leading to contractual renegotiations for both PPP and public procured cases [39-42].

Amongst the performance proxies, actual versus forecasted traffic as an indicator of performance implies that forecasts were accurate. This is not always the case [43].

A key challenge facing this research, given the comparative nature of "performance" (actual versus forecasted), is to identify when forecasts were inaccurate, especially since traffic demand is derived and correlated to macroeconomic developments. Hence, when positive or stable macroeconomic conditions prevail, then failure to meet traffic forecasts may be attributed to inaccurate estimates. Alternatively, assumptions need to be made and assessed through the qualitative description accompanying each case study.

On a second level, all projects are also assessed with respect to other project goals including transportation, social, environmental, and institutional outcomes. All outcomes are assessed on a scale of $[-2,1]$, ranging from far below expectations to above expectations.

The case description variable values are provided in Table 2 . The variables were, initially, qualitatively assessed. More specifically, during data collection, assessment was guided through specific questions researchers responded to. Answers were then centrally coded leading to the numerical assessment presented in Table 2. 
Table 2. Case description.

\begin{tabular}{|c|c|c|c|c|c|c|c|c|c|c|c|c|c|c|c|c|c|c|}
\hline Project Title (Country) & 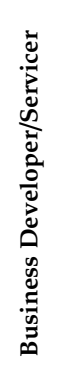 & 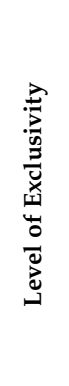 & 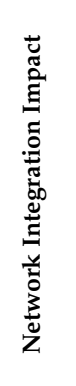 & 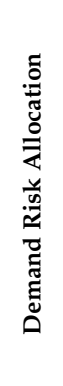 & 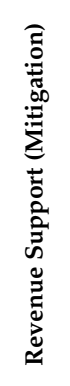 & 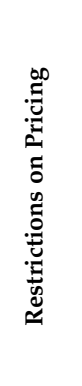 & 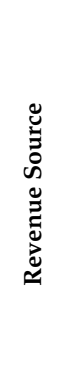 & 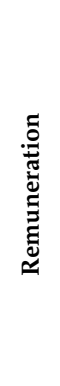 & 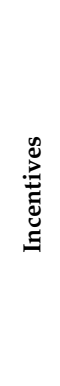 & 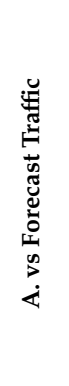 & 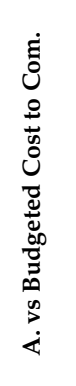 & 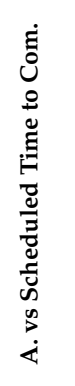 & 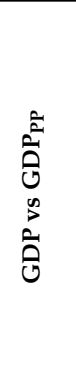 & 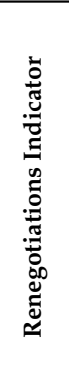 & 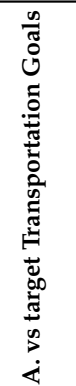 & 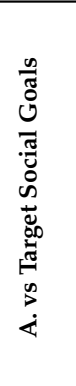 & 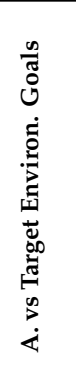 & 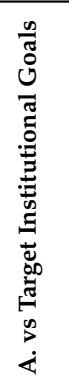 \\
\hline & \multicolumn{18}{|c|}{ Public Private Partnership Projects } \\
\hline & \multicolumn{18}{|c|}{ Motorways } \\
\hline PM.1. Athens Ring Road (GR) & 1 & 5 & 2 & 6 & 1 & 1 & 3 & 3 & $c$ & 1 & 0 & 0 & -1 & 1 & 1 & 1 & 1 & 1 \\
\hline PM.2. BreBeMi (IT) & 1 & 1 & -1 & 5 & 2 & 2 & 3 & 3 & 0 & -1 & -1 & -1 & -1 & 0 & n.a. & n.a. & n.a. & n.a. \\
\hline PM.3. BNRR (M6 TOLL) (UK) & 3 & 1 & -1 & 6 & 0 & 0 & 3 & 3 & 0 & -1 & 0 & 0 & 1 & 1 & 0 & 0 & 0 & 0 \\
\hline PM.4. M80 Haggs (UK) & 2 & 3 & 0 & 4 & 0 & n.a. & 1 & 1 & 1 & 0 & 0 & 0 & 0 & 0 & 0 & 0 & 0 & 0 \\
\hline PM.5. A19 Dishforth to Tyne Tunnel (UK) & 2 & 1 & 0 & 5 & 0 & n.a. & 1 & 1 & 0 & 0 & 0 & 0 & 0 & 0 & 0 & 0 & 0 & 0 \\
\hline PM.6. EJE Aeropuerto (M-12) (ES) & 2 & 1 & -1 & 6 & 0 & 2 & 3 & 3 & 0 & -2 & -1 & -1 & -1 & 1 & 0 & 0 & 0 & 0 \\
\hline PM.7. A22-Algarve (ES) & 1 & 3 & 1 & 2 & 2 & 3 & 2 & 2 & 1 & -2 & 0 & 0 & n.a. & 1 & -2 & -2 & -2 & -2 \\
\hline PM.8. Radial 2 Toll Road (ES) & 2 & 1 & 1 & 6 & 0 & 2 & 3 & 3 & 0 & -2 & -2 & -2 & -1 & 1 & 0 & 0 & 0 & 0 \\
\hline PM.9. M-45 (ES) & 2 & 2 & 0 & 6 & 0 & n.a. & 1 & 1 & 0 & 1 & -1 & 0 & -1 & 1 & 0 & 0 & 0 & 0 \\
\hline PM.10.A2 Motorway (PL) & 1 & 4 & 2 & 1 & 0 & 3 & 1 & 1 & 0 & 1 & 0 & 0 & n.a. & 0 & 1 & 1 & 1 & 1 \\
\hline PM.11.Istrian Y Motorway (HR) & 2 & 5 & 3 & 5 & 0 & 3 & 2 & 2 & 0 & 1 & 0 & 0 & 1 & 1 & 0 & 0 & 0 & 0 \\
\hline
\end{tabular}


Table 2. Cont

\begin{tabular}{|c|c|c|c|c|c|c|c|c|c|c|c|c|c|c|c|c|c|c|}
\hline PM.12.A23-Beira Interior (PO) & 2 & 3 & 2 & 1 & 2 & 3 & 2 & 2 & 1 & -2 & 0 & 0 & n.a. & 1 & -2 & -2 & -2 & -2 \\
\hline PM.13.E39 Orkdalsvegen Public Road (NO) & 1 & 4 & 2 & 2 & 0 & 3 & 3 & 3 & 1 & 1 & 0 & 0 & 1 & 0 & 1 & 1 & 1 & 0 \\
\hline PM.14.Via-Invest Zaventem (BE) & 2 & 6 & 3 & 2 & 1 & n.a. & 1 & 1 & 1 & 0 & 1 & 1 & 1 & 0 & 0 & 0 & 0 & 0 \\
\hline PM.15.E18 Grimstad-Kristiansand (NO) & 1 & 5 & 2 & 2 & 0 & n.a. & 1 & 1 & 1 & 0 & 0 & 0 & 1 & 0 & 0 & 0 & 0 & 0 \\
\hline PM.16.Moreas Motorway (GR) & 1 & 5 & 2 & 4 & 2 & 2 & 3 & 3 & 0 & -1 & -1 & -1 & -1 & 1 & 0 & 0 & 0 & 0 \\
\hline PM.17.C-16 Terrassa-Manresa Toll M/way (ES) & 2 & 2 & 1 & 4 & 0 & 2 & 3 & 3 & 0 & -1 & -1 & 0 & -1 & 0 & 0 & 0 & 0 & 0 \\
\hline PM.18.E18 Muurla-Lohja (FI) & 2 & 4 & 2 & 6 & 0 & n.a. & 1 & 1 & 1 & 0 & 0 & 0 & 0 & 0 & 0 & 0 & 0 & 0 \\
\hline PM.19.E4 Helsinki-Lahti (FI) & 1 & 5 & 2 & 5 & 0 & 0 & 1 & 1 & 1 & 1 & 0 & 0 & 0 & 0 & 0 & 0 & 0 & 0 \\
\hline & \multicolumn{18}{|c|}{ Bridge \& Tunnel } \\
\hline PB.1. Rion-Antirion Bridge (GR) & 1 & 5 & 3 & 6 & 1 & 2 & 3 & 3 & 0 & 1 & 0 & 1 & -1 & 0 & 1 & 1 & 0 & 1 \\
\hline PB.2. Lusoponte-Vasco da Gama Bridge (PO) & 1 & 6 & 3 & 4 & 2 & 3 & 3 & 3 & 1 & 1 & 0 & 0 & 0 & 0 & 0 & 0 & 0 & 0 \\
\hline PB.3. The Oresund Link (SE/DK) & 1 & 5 & 3 & 2 & 1 & 1 & 3 & 3 & 0 & 1 & 0 & 0 & 0 & 0 & 1 & 1 & 0 & 1 \\
\hline PB.4. Millau Viaduct (FR) & 2 & 4 & 3 & 6 & 0 & 2 & 3 & 3 & 0 & 1 & 0 & 0 & 0 & 0 & 0 & 0 & 0 & 0 \\
\hline PB.5. Coen Tunnel (NL) & 1 & 5 & 2 & 2 & 0 & n.a. & 1 & 1 & 1 & 0 & 0 & 0 & 0 & 0 & 0 & 0 & 0 & 0 \\
\hline & \multicolumn{18}{|c|}{ Ports } \\
\hline PP.1. Piraeus Container Terminal (GR) & 6 & 5 & 1 & 6 & 0 & 0 & 3 & 3 & 0 & 1 & 0 & 0 & -1 & 1 & 0 & 0 & 0 & 1 \\
\hline PP.2. Port of Sines Terminal XXI (PO) & 5 & 5 & 1 & 5 & 0 & 0 & 3 & 3 & 0 & -1 & 0 & -1 & n.a. & 0 & 0 & -1 & 0 & -1 \\
\hline $\begin{array}{l}\text { PP.3. Adriatic Gateway Container Terminal } \\
\text { (HR) }\end{array}$ & 5 & 5 & 3 & 4 & 0 & 0 & 3 & 3 & 0 & -1 & 0 & 0 & 1 & 0 & 0 & 0 & 0 & 0 \\
\hline
\end{tabular}


Table 2. Cont

\begin{tabular}{|c|c|c|c|c|c|c|c|c|c|c|c|c|c|c|c|c|c|c|c|}
\hline \multirow[b]{2}{*}{ PA.1. } & \multirow[b]{2}{*}{ Athens International Airport (GR) } & \multicolumn{18}{|c|}{ Airports } \\
\hline & & 5 & 6 & 3 & 5 & 0 & 0 & 2 & 2 & 0 & -1 & 0 & 0 & -1 & 0 & 1 & 1 & 1 & 0 \\
\hline \multirow[t]{2}{*}{ PA.2. } & Larnaca and Paphos Int. Airports (CY) & 5 & 6 & 3 & 5 & 0 & 0 & 2 & 2 & 0 & -1 & 0 & 0 & -1 & 0 & 1 & 0 & 0 & 0 \\
\hline & & \multicolumn{18}{|c|}{ Light//Heavy Rail } \\
\hline PR.1. & Metrolink LRT, Manchester (UK) & 1 & 6 & 1 & 4 & 2 & 2 & 3 & 3 & 0 & 1 & 0 & 0 & n.a. & 1 & 0 & 0 & 0 & 0 \\
\hline PR.2. & Reims tramway (FR) & 2 & 5 & 3 & 5 & 2 & 2 & 2 & 2 & 1 & -1 & -1 & -1 & n.a. & 1 & 0 & 0 & 1 & -1 \\
\hline PR.3. & Brabo $1(\mathrm{BE})$ & 2 & 1 & 1 & 2 & 2 & 1 & 2 & 2 & 1 & 0 & -1 & 1 & 1 & 0 & 0 & 0 & 0 & 0 \\
\hline PR.4. & Metro do Porto S.A. (PO) & 2 & 5 & 2 & 1 & 2 & 3 & 2 & 2 & 0 & -2 & 1 & 0 & n.a. & 0 & 0 & 0 & 0 & -1 \\
\hline \multirow[t]{2}{*}{ PR.5. } & Metro de Malaga (ES) & 2 & 4 & 2 & 2 & 2 & 2 & 2 & 2 & 0 & 0 & -1 & -1 & -1 & 1 & 0 & 0 & 0 & 0 \\
\hline & & \multicolumn{18}{|c|}{ Bicycles } \\
\hline PC.1. & Sevici (ES) & 6 & 1 & 0 & 6 & 0 & 2 & 3 & 3 & 0 & 0 & 0 & 0 & 0 & 1 & 0 & 0 & 0 & 0 \\
\hline \multirow[t]{3}{*}{ PC. 2 . } & Velo V (FR) & 3 & 5 & 0 & 6 & 0 & 2 & 2 & 2 & 1 & 1 & -1 & 0 & n.a. & 0 & 0 & 0 & 0 & 0 \\
\hline & & \multicolumn{18}{|c|}{ Public/Traditional Delivery Projects } \\
\hline & & \multicolumn{18}{|c|}{ Motorways } \\
\hline TM.1. & $\begin{array}{l}\text { M 75, Sec. Horgos-Novi Sad (ph2.) } \\
\text { (RO) }\end{array}$ & 1 & 5 & 2 & 1 & 0 & 3 & 0 & & 0 & -1 & -1 & -1 & -1 & 0 & 0 & 0 & 0 & 0 \\
\hline TM.2. & $\begin{array}{l}\text { Belgrade By-pass Project, Section A } \\
\text { (RO) }\end{array}$ & 1 & 4 & 2 & 1 & 0 & & 0 & & 0 & -2 & 0 & -1 & -1 & & 0 & 0 & 0 & 0 \\
\hline TM.3. & $\begin{array}{l}\text { M E-75, Sec. Donji Neradovac-Srpska } \\
\text { Kuca (RO) }\end{array}$ & 1 & 3 & 2 & 1 & 1 & 3 & 0 & & 0 & 0 & -1 & -1 & 0 & & 0 & 0 & 0 & 0 \\
\hline TM.4. & Combiplan Nijverdal (NL) & 1 & 5 & 3 & 1 & 1 & 0 & 0 & & & -1 & -1 & -1 & 1 & & 0 & 0 & 0 & 0 \\
\hline TM.5. & A5 Maribor-Pince Motorway (SI) & 1 & 1 & 2 & 1 & 0 & 3 & 0 & & 0 & 1 & 1 & 0 & 1 & & 1 & 1 & 1 & 0 \\
\hline
\end{tabular}


Table 2. Cont.

\begin{tabular}{|c|c|c|c|c|c|c|c|c|c|c|c|c|c|c|c|c|c|c|c|}
\hline \multirow[b]{2}{*}{ TT.1. } & \multirow[b]{2}{*}{ Blanka Tunnel (CZ) } & \multicolumn{18}{|c|}{ Tunnel } \\
\hline & & 1 & 4 & 3 & 1 & 1 & & 0 & & & 1 & -2 & -2 & 1 & & -1 & -1 & -1 & -1 \\
\hline \multirow[t]{2}{*}{ ТТ.2. } & Sodra Lanken (The southern Link) (SE) & 1 & 5 & 3 & 1 & 1 & 0 & 0 & & & 0 & -2 & -2 & 1 & & n.a. & n.a. & n.a. & n.a. \\
\hline & & \multicolumn{18}{|c|}{ Airports } \\
\hline TA.1. & Modlin Regional Airport (PL) & 5 & 1 & -3 & 2 & 0 & 3 & & & 0 & -2 & -1 & -1 & 1 & & -2 & -1 & 0 & -1 \\
\hline \multirow[t]{2}{*}{ TA.2. } & Berlin Brandenburg Airport (DE) & 4 & 5 & 3 & 1 & & & 3 & & & 1 & -2 & -1 & 1 & & & & & \\
\hline & & \multicolumn{18}{|c|}{ Light/Heavy Rail } \\
\hline TR.1. & Tram T4 (Line 4 of Lyon Tramway) (FR) & 1 & 5 & 3 & 4 & 1 & 3 & & & 1 & 1 & 0 & 0 & -1 & & 0 & 1 & 0 & 0 \\
\hline TR.2. & Athens Tramway (GR) & 1 & 2 & 1 & 1 & 0 & 3 & & & 0 & -2 & -1 & 0 & -1 & & 0 & 0 & 0 & 0 \\
\hline TR.3. & Attiko Metro (GR) & 1 & 5 & 2 & 2 & 2 & 0 & 2 & 0 & & 1 & -2 & -2 & -1 & & 0 & 0 & 0 & 0 \\
\hline TR.4. & Warsaw's Metro II-nd line (PO) & 1 & 3 & 2 & 1 & 0 & 3 & & & 0 & 0 & -1 & -1 & 1 & & 0 & 0 & 0 & 0 \\
\hline TR.5. & $\begin{array}{l}\text { Gardermobanen (Airport Exprestrain) } \\
\text { (SE) }\end{array}$ & 1 & 5 & 3 & 1 & 2 & 0 & 3 & 0 & & 1 & -1 & 0 & 0 & & 1 & 1 & 0 & 1 \\
\hline TR.6. & HSL-Zuid (NL/BE) & 3 & 1 & 3 & 1 & & & 3 & 0 & & 1 & -2 & -2 & 1 & 1 & 0 & 0 & 0 & 0 \\
\hline
\end{tabular}

Source: [35-38]. Legend: n.a. = not available. Coding legend: $\mathrm{P}=$ Public Private Partnerships (PPPs); $\mathrm{T}=$ traditional procurement; $\mathrm{M}=$ motorway; $\mathrm{B}=$ bridge/tunnel; $\mathrm{P}=$ port; $\mathrm{A}=$ airport; $\mathrm{R}=$ light/heavy rail; $\mathrm{C}=$ bicycle; $\mathrm{T}=$ tunnel. 


\subsection{Methodology}

The present research builds on the work of Roumboutsos and Pantelias [27], introducing, initially, the composite indicator "level of control" ( $L O C)$, which characterizes the infrastructure by encompassing the attributes of "business developer/servicer", "level of exclusivity" or the strength of the temporary monopoly and the "impact the transport network" has on the "level of exclusivity". Then, a second indicator is constructed comparing the "level of control" to the demand risk allocation and presenting the measure of optimality in this allocation, termed "optimal demand risk allocation index" (ODA). Following their construction, the proposed indicators are validated and assessed. Their importance as a measure of project sustainability, especially in complex projects, is demonstrated.

\subsubsection{Composite Indicators}

Composite indicators have become important tools in describing and putting forward tendencies of complex systems. Over time, their use and applicability have been questioned and debated by many researchers [44]. Initially, composite indicators were used to assess countries based on economic, social, and institutional measures. Their great advantage is in their potential to represent a "complex system" consisting of numerous "components". The effort is to reflect the system with the least number of parts.

The European Commission [45] and the OECD [46] produced guidelines as per their construction so as to secure transparency and avoid data manipulation and misrepresentation. The proposed steps of construction include: theoretical framework describing the "complex system"; data selection to represent the system, as well as proxies when needed; imputation of missing data; multivariate analysis to assess the correlation and potential weighting; normalisation of indicators to make them comparable; weighting and aggregation.

\subsubsection{The Composite Indicator Level of Control (LoC)}

Figure 1 represents the theoretical framework connecting the attributes of the transport infrastructure, which build control in terms of demand. The three variables, F.1, F.2 and F.3 (see Table 1), are combined to produce the composite indicator level of control (LoC). Four approaches were considered, stemming from Figure 1, which are described below:

i. The LoC configuration assumes that the maximum possible level of exclusivity is achieved when the network integration completely favours the infrastructure, and therefore [F.2 + F.3] and normalised in the range [0,6]. Then, the maximum potential for business or service provision is achieved for the maximum possible exclusivity, leading to the maximum "level of control" generated as the product. The indicator is then normalised in the range [1,6].

$$
L O C 1=\frac{F .1 \times \frac{(F .2+F .3+2) \times 6}{14}}{6}=\frac{F .1 \times(F .2+F .3+2)}{14}
$$

ii. The LoC configuration assumes that the maximum possible level of exclusivity is achieved when the network integration completely favours the infrastructure, as in LOC1. Then, the potential for business or service provision is added to give the "level of control". The indicator is then normalised in the range $[1,6]$.

$$
L O C 2=\frac{F .1+\frac{(F .2+F .3+2) \times 6}{14}}{2}=\frac{F .1}{2}+\frac{3 \times(F .2+F .3+2)}{14}
$$

iii. The $L o C$ configuration assumes the simple aggregation of all three variables. The indicator is then normalised in the range $[1,6]$.

$$
L O C 3=\frac{(F .1+F .2+F .3) \times 6}{16}=\frac{3 \times(F .1+F .2+F .3)}{8}
$$


iv. As in LOC3 but assuming that the level of exclusivity and network impact bear double weight versus the business scope. The indicator is then normalised in the range [1,6]. This latter configuration may be considered arbitrary as per the weighting applied.

$$
L O C 4=\frac{[F .1+(F .2+F .3) \times 2] \times 6}{28}=\frac{3 \times F .1}{14}+\frac{3 \times(F .2+F .3)}{7}
$$

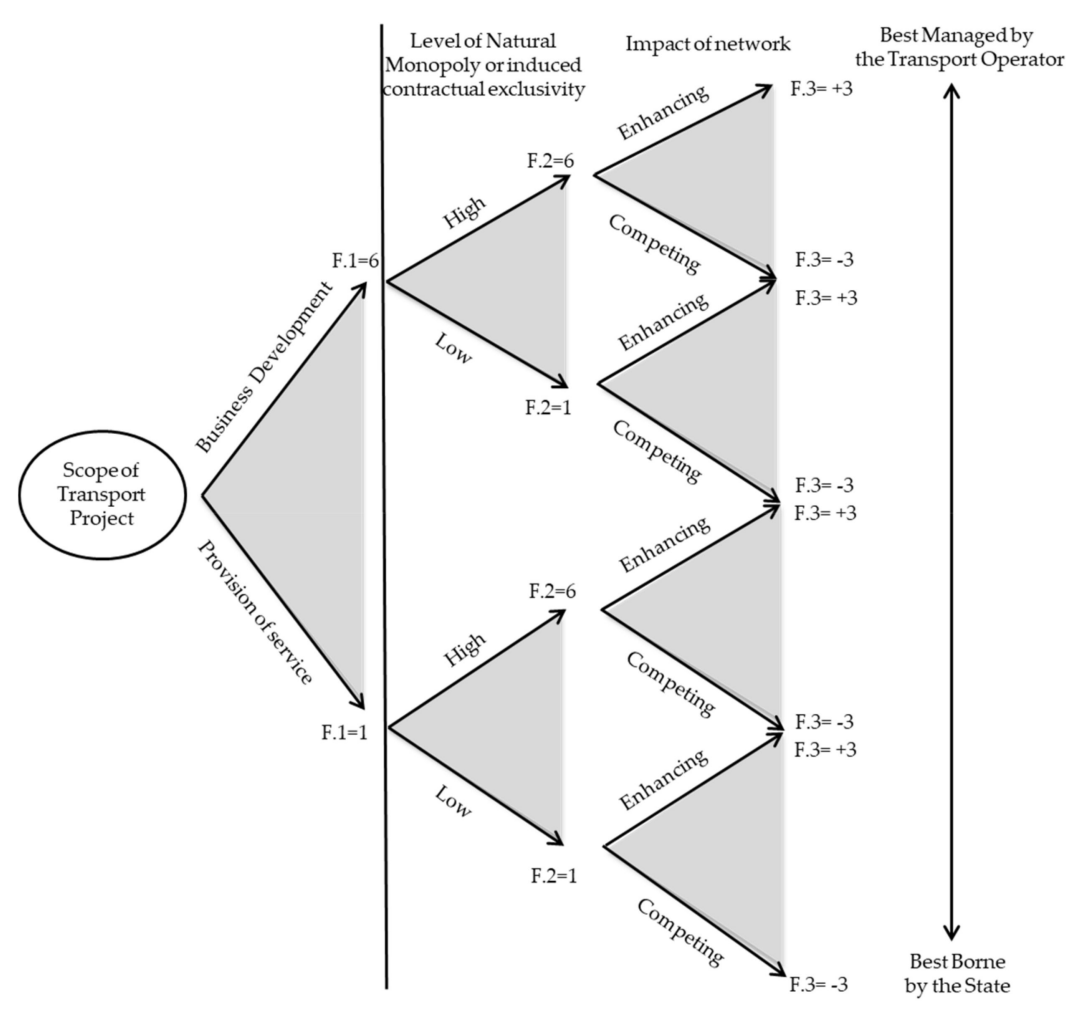

Figure 1. Level of control system configuration adjusted from [27].

The constructed composite indicators are then validated based on the following criteria, so as to select the most suitable one. The criteria conform with the steps suggested for the construction of composite indicators $[45,46]$. The criteria employed are:

- Representation and coherence with the qualitative assessment of the cases represented.

- Correlation to theoretical underpinnings.

- Fitness for purpose, in terms of providing adequate variation and simplicity.

These criteria are used in the analyses presented in the next section and leading to the selection of the most accommodating LoC configuration.

\subsubsection{The Indicator "Optimal Demand Risk Allocation" (ODA)}

Optimal risk allocation is assessed by comparing the $L o C$ to the effected risk allocation. This concerns comparing $L O C$ with demand risk allocation (C.1 of Table 1), as:

$$
O D A=L O C-C .1\left\{\begin{array}{c}
> \\
+1, \text { suboptimal with more risk retained by the public sector } \\
-1 \leq O D A \leq+1, \text { optimal } \\
<-1 \text {, suboptimal with more risk allocated to the operator }
\end{array}\right.
$$

It is observed that optimal demand risk allocation is assessed for $O D A \in[-1,1]$ and not as $O D A \approx 0$, taking into consideration the fuzziness in assessing both $L o C$ and demand risk allocation. 
The indicator "optimal demand risk allocation" $(O D A)$ is analysed against project performance with respect to forecast versus observed traffic and the potential project sustainability.

\subsubsection{Assessment of Performance}

Actual versus forecasted traffic as a performance proxy bears limitations. Inaccurate initial estimates [43] are a principal source of concern. However, there may be a significant difference between the ex-ante estimated traffic and actual traffic observed during the first years of operation [47]. In addition, achievement of traffic targets also reflects achieving other project targets including social, environmental and/or institutional targets.

Variations in predicted traffic volumes are also dependent on macroeconomic conditions. The basic assumption followed in the present analysis is: the "traffic demand vs forecasted" indicator should follow the macroeconomic proxy indicator.

When the above assumption (hypothesis) does not hold true, further investigation is required to identify whether the variation is due to inaccurate forecasts or contractual structural issues and in this case, demand risk allocation. In order to systematically consider the above hypothesis, the analysis is considered in three sample groups:

Group 1 (G1): When the variance in actual vs forecast traffic compares to the variance in the expected GDP.

Group 2 (G2): When actual vs forecast traffic is better than the variance due to GDP.

Group 3 (G3): When the actual vs forecast traffic is worse than could be reasonably explained by the variance of GDP.

\section{Results}

\subsection{Dataset Analysis}

The listed 51 case studies of transport infrastructure projects were used to structure and assess the $L O C$. Then, the ODA was calculated and assessed against project performance. It should be noted that the present sample cannot be considered as representative. However, the cases that comprise this sample provide a useful benchmark for the current analysis, since they include both PPP and public funded projects, covering a wide range of transport infrastructure modes in 19 European countries. This essentially renders the sample random, eliminates bias in the analysis and allows for a number of general observations to be made and/or key trends to be identified. Table 2 shows the correlations between the variables registered for each of the 51 project cases. Kendall's tau-b non-parametric test was used given the size of the sample and the fact that many variables are ordinal, especially those indicating performance. In the correlation (Table 3), it is interesting to note that, within the specific sample, PPP projects are related to positive performance with respect to cost and time to construction completion. Additionally, as assumed in Section 2.2.4, the achievement of the project traffic/demand goals corresponds to a better performance with respect to other transport goals (Trans) as well as social and institutional (Inst.) goals. The same does not apply for environmental (Env.) goals. Projects characterised as a "link" (e.g., roads) show correlation to renegotiations (REG). Finally, the well documented relation between growth (GDP) and traffic is not present, suggesting the existence of a number of inaccurate forecasts distorting the correlation results.

Results are presented on two levels: those related to the validation of the proposed composite indicators, $L O C$ and $O D A$, and those that correspond to the respective assessment of project performance as per $O D A$ leading to lessons learned. 
Table 3. Kendall's tau-b correlation.

\begin{tabular}{|c|c|c|c|c|c|c|c|c|c|c|c|}
\hline & PPP & Link & Traffic & Cost & Time & GDP & REG & Trans & Social & Env. & Inst. \\
\hline Cor. Coef. & 1.000 & 0.011 & -0.052 & $\underset{* *}{0.453}$ & $\underset{* *}{0.503}$ & -0.267 & -0.051 & 0.112 & -0.006 & 0.083 & 0.054 \\
\hline \multirow[t]{13}{*}{ Sig. (2-tailed) } & & 0.936 & 0.689 & 0.001 & 0.000 & 0.067 & 0.758 & 0.430 & 0.965 & 0.562 & 0.699 \\
\hline & & 1.000 & 0.109 & 0.049 & -0.013 & 0.055 & $\begin{array}{c}-0.360 \\
*\end{array}$ & 0.087 & -0.063 & -0.077 & 0.032 \\
\hline & & & 0.401 & 0.712 & 0.924 & 0.704 & 0.028 & 0.541 & 0.655 & 0.587 & 0.819 \\
\hline & & & 1.000 & 0.053 & 0.197 & 0.097 & -0.094 & $\underset{* *}{0.356}$ & $\underset{* *}{0.443}$ & 0.207 & $\underset{* *}{0.492}$ \\
\hline & & & & 0.667 & 0.111 & 0.473 & 0.533 & 0.006 & 0.001 & 0.114 & 0.000 \\
\hline & & & & 1.000 & $\begin{array}{c}0.677 \\
* *\end{array}$ & 0.094 & -0.309 & 0.255 & 0.219 & 0.174 & 0.076 \\
\hline & & & & & 0.000 & 0.495 & 0.050 & 0.058 & 0.101 & 0.199 & 0.567 \\
\hline & & & & & 1.000 & -0.022 & $\begin{array}{c}-0.361 \\
*\end{array}$ & $\begin{array}{c}0.300 \\
*\end{array}$ & $\begin{array}{c}0.320 \\
*\end{array}$ & 0.093 & $\begin{array}{c}0.292 \\
*\end{array}$ \\
\hline & & & & & & 0.871 & 0.022 & 0.026 & 0.017 & 0.493 & 0.029 \\
\hline & & & & & & 1.000 & -0.194 & -0.210 & -0.210 & -0.071 & -0.322 \\
\hline & & & & & & & 0.269 & 0.156 & 0.156 & 0.633 & 0.030 \\
\hline & & & & & & & 1.000 & $\begin{array}{c}-0.338 \\
*\end{array}$ & -0.250 & -0.145 & -0.114 \\
\hline & & & & & & & & 0.039 & 0.122 & 0.376 & 0.475 \\
\hline
\end{tabular}

Note: * Correlation is significant at the 0.05 level (2-tailed); ${ }^{* *}$ Correlation is significant at the 0.01 level (2-tailed).

\subsection{Selecting the Most Appropriate Formulation of LoC}

Selection of the most suitable configuration of $L o C$ is based on the criteria defined in the Section 2.2.2.

Criterion 1: representation and coherence with the qualitative assessment of the cases represented.

Figure 2 shows the $L o C$ indicator values calculated for the 51 projects in the sample for each proposed configuration of the indicator. All configurations could be considered representative of the level of control the various infrastructures may demonstrate. For example, projects PM.1-PM.19, referring to roads and motorways, illustrate a relatively lower $L o C$ than, for example, projects PB.1-PB.5 (bridge and tunnel) or PP.1-PP.3 and PA.1-PA.2, which refer to ports and airports, respectively (see Table 2). The Athens Ring Road (PM.1), the Istrian Y Motorway (PM.11) and Via-Invest (PM.14) are exceptions due to their unique features. Hence, all four configurations are considered to address this criterion.

Criterion 2: correlation to theoretical underpinnings.

Multivariate analysis is proposed $[43,44]$ to test for correlations and assumptions. The key assumption considered herewith with respect to LoC is: an infrastructure demonstrating high LoC will be able to secure traffic.

However, this hypothesis can only be proven within the sub-sample of accurate traffic forecasts. The probability of accuracy is greater for cases within the G1 sample group defined previously (see Section 2.2.4). In addition, in order to minimise the statistical disorder, the scale of values for traffic and the $L o C$ configurations was normalised. Following this approach, Table 4 shows the respective non-parametric Kendall's tau-b and Spearman's how it is known correlations. The normalised values of LoC3 and LoC4 are the configurations showing the anticipated correlations.

Criterion 3: fitness for purpose, in terms of providing adequate variation and simplicity.

Referring to Figure 2, both $L O C 3$ and LoC4 present variation, making the respective indicators suitable for comparisons. When also considering "simplicity", the third configuration (LoC3) was selected as the one matching all the criteria and also as the easiest to construct as it corresponds to the simple aggregation of the three factors considered, with no weighting included. Notably, this is one of the most common approaches to the construction of composite indicators [48]. 


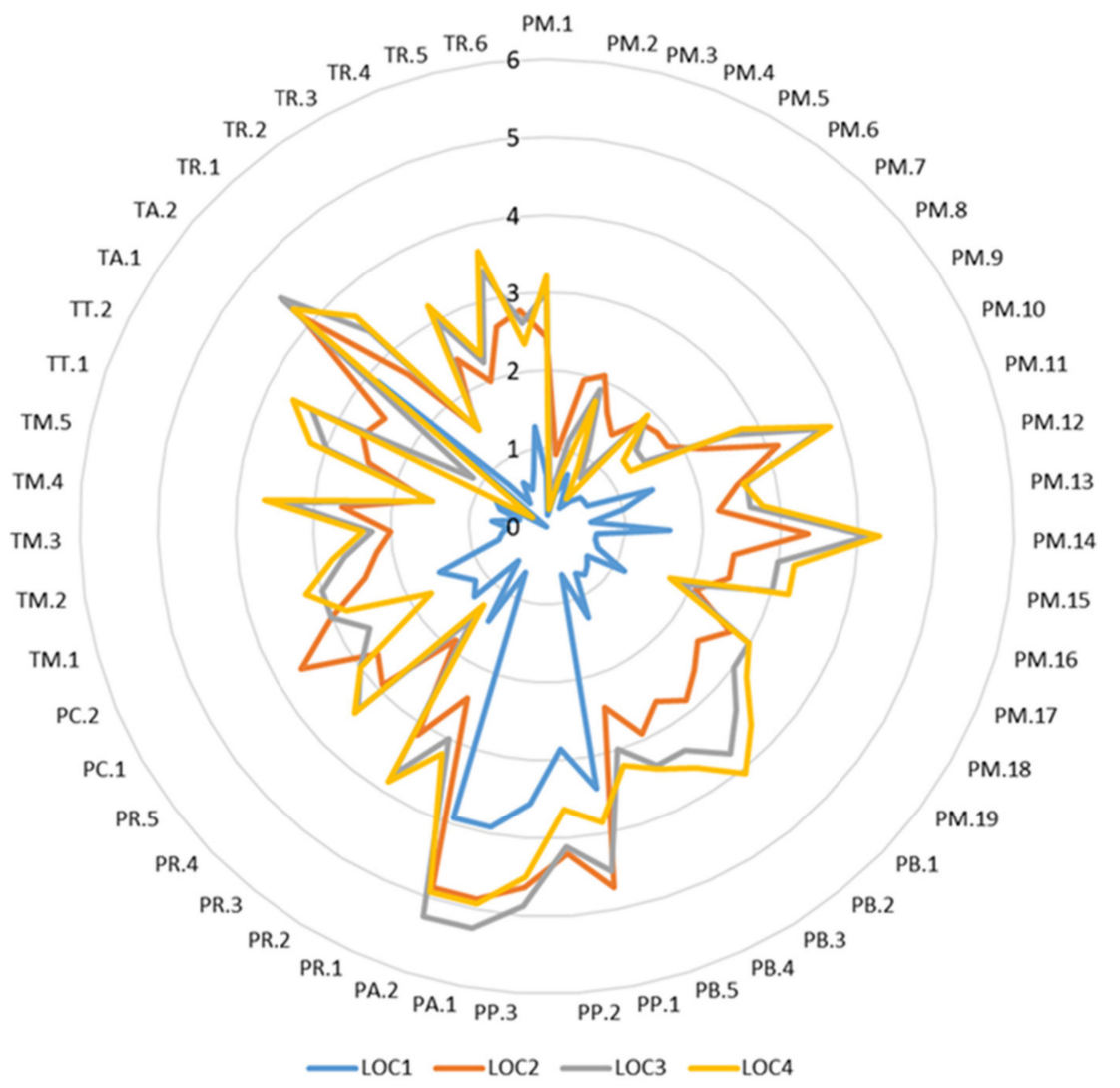

Figure 2. Visualisation of the level of control $(L o C)$ configurations. Coding legend: $\mathrm{P}=\mathrm{PPP}$; $\mathrm{T}=$ traditional procurement; $\mathrm{M}=$ motorway; $\mathrm{B}=$ bridge/tunnel; $\mathrm{P}=$ port; $\mathrm{A}=$ airport; $\mathrm{R}=$ light/heavy rail; $\mathrm{C}=$ bicycle; $\mathrm{T}=$ tunnel.

Table 4. Kendall's tau-b and Spearman's how it is known correlation for traffic and LoC.

\begin{tabular}{|c|c|c|c|c|c|c|}
\hline & & \multirow{2}{*}{$\begin{array}{l}\text { Normalised Traffic } \\
\text { Assessment }\end{array}$} & \multicolumn{4}{|c|}{ Normalised } \\
\hline & & & LoC1 & LoC2 & LoC3 & LoC4 \\
\hline \multirow{2}{*}{ Kendall's tau-b } & Correlation Coefficient & 1.000 & 0.157 & 0.223 & $0.305^{*}$ & $0.296 *$ \\
\hline & Sig. (2-tailed) & & 0.255 & 0.104 & 0.030 & 0.032 \\
\hline \multirow{2}{*}{ Spearman's rho } & Correlation Coefficient & 1.000 & 0.186 & 0.272 & $0.339 *$ & 0.341 * \\
\hline & Sig. (2-tailed) & & 0.277 & 0.109 & 0.043 & 0.042 \\
\hline
\end{tabular}

Note: * Correlation is significant at the 0.05 level (2-tailed).

\subsection{Optimal Demand Risk Allocation}

Figure 3 illustrates the optimal demand risk allocation indicator of the projects in our sample. Private sector operators of roads and motorways seem to be shouldering more demand risk than may be justified. This has been a characteristic of the PPP model in Europe for motorways, prior to the 2008/2009 global financial crisis [49]. The ports and airports are better suited for the demand risk transferred to the private operator. Amongst the traditionally procured projects, there are cases where demand risk could be reasonably transferred to the operator such as the Berlin Brandenburg Airport (TA.2), Sodra Lanken (The Southern Link) (TT.2) or Combiplan Nijverdal (TM.4). Notably, the Berlin airport was initially considered as a PPP project. 


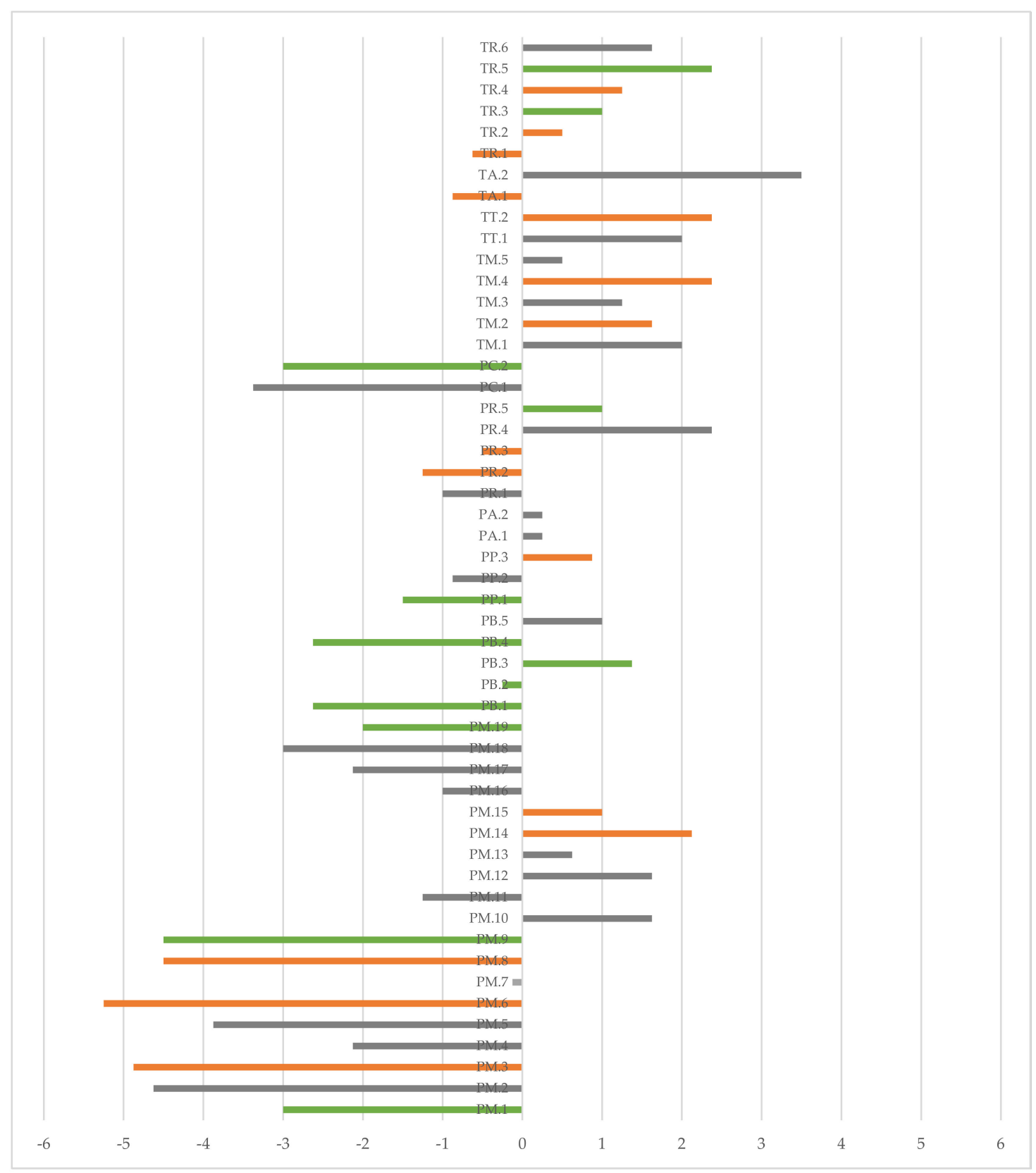

Figure 3. Optimal demand risk allocation indicator values. Colour coding legend: grey performed in line with GDP (group G1); green performed better than forecasted traffic and GDP (group G2); red performed worse than GDP (group G3). Coding legend: $\mathrm{P}=\mathrm{PPP} ; \mathrm{T}=$ traditional procurement; $\mathrm{M}=$ motorway; $\mathrm{B}=$ bridge/tunnel; $\mathrm{P}=$ port; $\mathrm{A}=$ airport; $\mathrm{R}=$ light/heavy rail; $\mathrm{C}=$ bicycle; $\mathrm{T}=$ tunnel.

Figure 3 also illustrates how projects have performed with respect to whether actual traffic corresponds to forecasts under the variance of GDP. Hence, grey charted projects belong to Group 1 (G1), green charted cases are those performing better than expected included in Group 2 (G2) and the red ones under Group 3 (G3). The latter potentially have inaccurate traffic forecasts, while the green charted projects suggest conservative estimates.

\subsubsection{Performance Assessment of ODA $\in[-1,1]$}

As illustrated in Figure 3, in 18 project cases (13 out of 36 PPP cases and five out of 15 traditionally procured cases) demand risk was allocated according to the LoC. Within the PPP sample of cases, eight performed as expected (Group 1-G1); two better (Group 2-G2) and three worse (Group 
3-G3). Checking against Table 2, it is interesting to note that despite this optimality, projects were contractually supported through grants, subsidies, and other respective risk mitigation measures. As such measures were not required or justified, the public sector experiences loss of value. Within the sample of traditionally procured projects, one performed as expected (G1); one better (G2) and three worse (G3). This finding implies optimism bias on behalf of the public sector [43]. In addition, it is important to note that in only two cases were PPP contracts renegotiated (see Table 2), suggesting reduced transaction costs.

\subsubsection{Performance Assessment of ODA $>1$}

This section refers to projects with more risk retained by the public sector with respect to the LoC demonstrated by the infrastructure. This fact results in the loss of incentives to excel by the operators. It includes 15 project cases ( 5 out of 36 PPP cases and 10 out of 15 traditionally procured cases) and only two project contracts include incentives.

Having $O D A>1$ is a common situation for traditionally procured projects with the operator (albeit an arm's-length public operator) responsible for managing less risk than could be justified. Amongst the traditionally procured projects, five (5) cases performed in line with variations in GDP (G1); one better (G2); and four worse than expected (G3). Gardermobanen (TR.5), in G2, also received revenue support. Most interesting are the five cases of G1, since the public sector is shouldering far more risk than needed and ultimately losing potential value. Such is the case of the Berlin airport, which is uniquely positioned with a high $L o C$ and the only case with $O D A>>2$. These are also projects that could be reasonably considered to be delivered as PPPs.

A few (5) PPP cases belong to this section, including one case that performed better (G2) and one that performed worse (G3), while the remaining three performed in-line with GDP variations. The A23-Beira Interior project was the only one renegotiated, implying only one case with revenues below expectations. This was also one of the two cases including contractual incentives of performance.

\subsubsection{Performance Assessment of ODA $<1$}

This assessment only includes PPP projects (16 out of 36 in the sample) illustrating the tendency of governments to pass demand risk over to the private sector [48]. This may be described as demand risk misallocation, which comes with a premium as the private operator shoulders this risk for a price. Amongst these cases, seven (7) performed as expected (G1) based on GDP variations; three performed worse (G3) and the remaining six (6) performed better (G2). Within the latter group, only three projects were not renegotiated; amongst them, the Rio-Antirio Bridge that was planned for over 100 years and the much-debated Millau Viaduct. The Birmingham Northern Relief Road (BNRR) motorway, the Eje Aeropuerto M-12 and the Radial 2 toll-way, all in G3, were renegotiated. Notably, the BNRR is a project considered as "failed" but with only one shortfall: "traffic", as otherwise the project met its cost and time to completion targets and is generating the anticipated revenues. Cases in this group are receiving revenue support, or their revenues include sources other than user payments. Hence, the image portrayed of this assessment is distorted by mitigation and other measures indicating loss of value for the public sector, while the number of renegotiated contracts suggests inaccurate traffic forecasts, which were later corrected.

\section{Discussion and Conclusions}

Efficient risk allocation has been proven to be at the heart of effective and efficient infrastructure project delivery [6]. Efforts have been made to provide governments with guidelines in an attempt to assist sustainable project delivery and secure added value for the public sector. However, while most risks may be reasonably assigned in transport infrastructure projects, demand risk remains ambiguous (see for example the 2019 edition of the Infrastructure Hub [10]). Trying to introduce operational incentives [5], governments usually transfer demand risk to the operator. This has been especially true for PPP projects before the Global Financial Crisis (GFC) [49]. However, following the GFC, 
risk averse behaviours prevailed, and operators were supported and guaranteed against demand and revenue risks [28]. Both strategies-passing on demand risk and protecting against/mitigating demand risk-lead to loss of value for the public sector and projects that are not sustainable.

The present research is the first attempt, to the authors' knowledge, to introduce tools that may guide contracting parties in assigning demand risk in transport infrastructure projects based on the level of managerial control over demand risk the operator may have. In this context, two composite indicators were constructed to represent the complex transport infrastructure project in this respect. The first, the level of control ( $\mathrm{LOC}$ ), describes the potential control over demand the key characteristics and attributes of the infrastructure in the transport network may offer an operator. The LoC composite indicator was constructed following accomplished rules set by supranational organisations $[45,46]$. The second, optimal demand risk allocation $(O D A)$, is seen as an assessment of the appropriateness of demand risk allocation based on the $L o C$ attribute with optimal values in the range $[-1,1]$; more risk than justifiably transferred to the operator when $O D A \in[-6,-1)$ and more risk retained by the public sector than beneficial when $O D A \in(1,6]$.

Furthermore, 51 project cases, ranging across different transport infrastructure modes, delivered through different procurement models (including PPP and traditional delivery), across various times (ranging from the early 1990s to 2015) and countries (19 European countries), were used to validate the construction of the LoC composite indicator and assess project performance based on ODA. A key limitation of the assessment is whether the project performance in terms of achieving forecasted traffic is a reflection of inaccurate forecasts or the influence of macroeconomic conditions. In order to overcome this limitation, performance was considered based on the co-variance with GDP. Figure 4 summarises the results of the respective analysis.

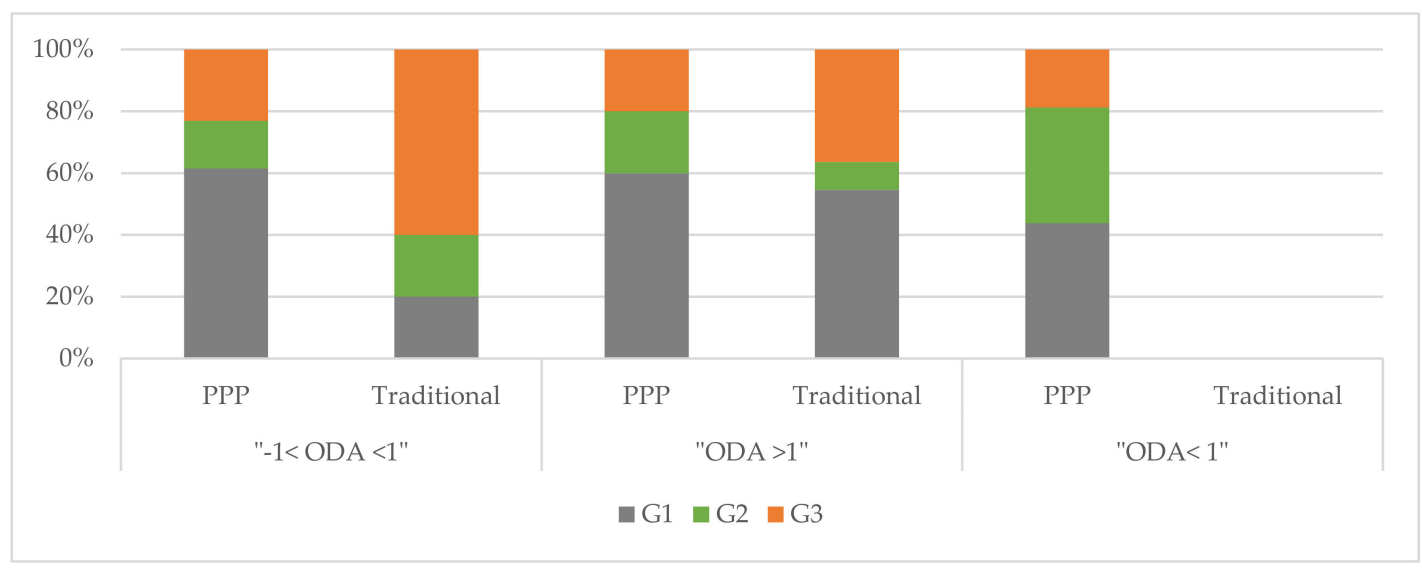

Figure 4. Public Private Partnerships (PPPs) and traditionally procured project cases assessed based on optimal demand risk allocation $(O D A)$. Colour coding legend: grey performed in line with GDP (G1); green performed better than forecasted traffic and GDP (G2); red performed worse than GDP (G3).

Projects performed as planned and in accordance with macroeconomic conditions in G1, have conservative forecasts in G2 and optimistic forecasts in G3. It is important to note the significance of achieving planned objectives [4]. This is especially true when considering traffic in transport projects as most economic, social, environmental, and institutional goals are related to traffic and, therefore, the project's sustainability goals.

Most PPP projects performed as planned when $O D A \in[-1,2]$. A lesser performance is observed when $O D A<-1$. In this section, a significant number of PPP projects formulated conservative forecasts. This is indicative of risk averseness resulting in the project not achieving its full potential and, consequently, resulting in loss of value. Moreover, in most PPP projects, the public sector passed on to the private operator more risk than could be justified by the level of control. This was achieved, 
obviously, at a price, while mitigation measures were also present. Most projects were also renegotiated, increasing yet again the cost of the project for the public sector.

Optimism bias [43] is more evident in traditionally procured projects. More demand risk was retained by the central government for most traditionally delivered projects. This approach reduces incentives. Amongst traditionally procured projects, based on their $L o C$, a number of projects were identified that could be financed by the private sector, saving funds for the public purse. This realisation is important at times when governments have to direct public funds to the social domain as in the case of the COVID-19 pandemic [34]. Hence, LoC is also an additional tool in the government toolbox, assessing the comparative value of PPP versus traditional procurement. Equally so, institutional financiers may also gain an understanding of the project's potential to control demand/revenue risk through a measure-an indicator-the financial sector is accustomed to.

In addition, $L O C$ is a dynamic indicator, which can accommodate changes that may occur over time. These include changes in scope, new infrastructure or innovation added to the transport network, changes in the level of integration with the transport network, not to mention changes in user behaviour that may change the infrastructure's level of exclusivity. Finally, the indicators ( $\mathrm{LoC}$ and $O D A$ ) adopt a holistic/horizontal approach and a rationale applicable to all types of infrastructure project delivery, without the need to distinguish among procurement types (PPP/public) or transport modes. The endorsement of the proposed composite indicators is all the more important when project complexity is increased due to natural non-controllable factors such as extreme weather events due to climate change or project exogenous factors impacting the economy, such as the current epidemic [50].

The proposed composite indicators do not include other factors included in the contractual agreement that influence the control the operator has over demand risk or the measures the government has introduced to mitigate/reduce risk. Many such cases were identified in the analysis. Their inclusion in contractual agreements aims at reducing operators' uncertainty and risk adverseness but when offered against inappropriate transfer of risk, it suggests further loss of value for the public and distorts the applicability of the indicator. Another important factor not included is the managerial skills of the operator. In this aspect, the $L o C$ describes the potential level of control. Future research should target a more inclusive $\mathrm{LoC}$ composite indicator. Finally, both indicators are currently not normalised in the commonly used range [0,1], as the greater range allows better visualisation.

The above assessment justifies the use the composite indicator level of control (LoC) as a novel indicator that illustrates the potential of an operator to managerially control demand risk in a transport infrastructure project. The optimal demand risk allocation $(O D A)$ has been shown to be a useful tool in assessing the appropriateness of demand risk allocation. The employment of these tools by parties-public and private-involved in transport infrastructure delivery ultimately leads to more accurate forecasts and, consequently, sustainable transport infrastructure as the project then delivers on its economic, environmental, and social/welfare targets.

Author Contributions: Conceptualization, A.R.; methodology, A.R. and A.T.-S.; analysis, A.R. and I.K.; validation, A.R. and A.T.-S.; writing-original draft, A.R. and I.K.; writing-review and editing, A.R., A.T.-S. and I.K. All authors have read and agreed to the published version of the manuscript.

Funding: The contents of this paper are partly based on research carried out within the framework of the Business Models for Enhancing Funding and Enabling Financing for Infrastructure in Transport (BENEFIT) project. The BENEFIT project has received funding from the European Union's Horizon 2020 research and innovation programme under grant agreement no 635973.

Conflicts of Interest: The authors declare no conflict of interest. 


\section{References}

1. Cigu, E.; Agheorghiesei, D.T.; Gavriluță (Vatamanu), A.F.; Toader, E. Transport Infrastructure Development, Public Performance and Long-Run Economic Growth: A Case Study for the EU-28 Countries. Sustainability 2019, 11, 67. [CrossRef]

2. Kivila, J.; Martinuso, M.; Vuorinen, L. Sustainable project management through project control in infrastructure projects. Int. J. Proj. Manag. 2017, 35, 1167-1183. [CrossRef]

3. Cabrera, M.; Suarez-Aleman, A.; Trujillo, L. Public-private partnerships in Spanish Ports: Current status and future prospects. Util. Policy 2015, 32,1-11. [CrossRef]

4. Johansen, A.; Olsson, N.O.E.; Jergeas, G.; Rolstadås, A. Project Risk and Opportunity Management: An Owner's Perspective; Routledge: London, UK, 2019.

5. Moore, M.A.; Boardman, A.E.; Vining, A.R. Analyzing risk in PPP provision of utility services: A social welfare perspective. Util. Policy 2017, 48, 210-218. [CrossRef]

6. Makovšek, D.; Moszoro, M. Risk pricing inefficiency in public-private partnerships. Transp. Rev. 2018, 38, 298-321. [CrossRef]

7. Garvin, M.; Bosso, D. Assessing the effectiveness of infrastructure public-Private partnership programs and projects. Public Work. Manag. Policy 2008, 13, 162-178. [CrossRef]

8. Jin, X.H.; Zhang, G. Modelling optimal risk allocation in PPP projects using artificial neural networks. Int. J. Proj. Manag. 2011, 29, 591-603. [CrossRef]

9. OECD. Transport Infrastructure Investment: Options for Efficiency; Organization for Economic Cooperation and Development, Joint Transport Research Centre: Paris, France, 2008.

10. Global Infrastructure Hub. PPP Risk Allocation Tool 2019 Edition-Transport, in Collaboration with Allen \& Overy, A G20 Initiative. 2020. Available online: https://www.gihub.org/resources/publications/ppp-risk-allo cation-tool-2019-edition/ (accessed on 2 October 2020).

11. Grimsey, D.; Lewis, M.K. Public Private Partnerships; UKA Edward Elgar: Cheltman, UK, 2004.

12. Le, P.T.; Kirytopoulos, K.; Chileshe, N.; Rameezdeen, R. Taxonomy of risks in PPP transportation projects: A systematic literature review. Int. J. Constr. Manag. 2019, 1-16. [CrossRef]

13. Wang, Y.; Wang, Y.; Wu, X.; Li, J. Exploring the Risk Factors of Infrastructure PPP Projects for Sustainable Delivery: A Social Network Perspective. Sustainability 2020, 12, 4152. [CrossRef]

14. Gossling, S. Risks, resilience and pathways to sustainable aviation: A COVID-19 perspective. J. Air Transp. Manag. 2020, 89. [CrossRef]

15. Loosemore, M.; Raftery, J.; Reilly, C.; Higgon, D. Risk Management in Projects; Taylor \& Francis: London, UK, 2006.

16. Evenhuis, E.; Vickerman, R. Transport pricing and Public-Private Partnerships in theory: Issues and Suggestions. Res. Transp. Econ. 2010, 30, 6-14. [CrossRef]

17. Olsson, N.O.E.; Johansen, A.; Langlo, A.J.; Torp, O. Project ownership: Implications on success measurement. Meas. Bus. Excell. 2008, 12,39-46. [CrossRef]

18. Gwilliam, K. Cities on the Move: A World Bank Urban Transport Strategy Review; World Bank: Washington, DC, USA, 2004.

19. Wang, J.Y.T.; Yang, H. A game-theoretic analysis of competition in a deregulated bus market. Transp. Res. Part E 2005, 4, 329-355. [CrossRef]

20. Roumboutsos, A.; Kapros, S. A game theory approach to urban public transport integration policy. Transp. Policy 2008, 15, 209-215. [CrossRef]

21. Siemiatycki, M.; Friedman, J. The Trade-Offs of Transferring Demand Risk on Urban Transit Public-Private Partnerships. Public Work. Manag. Policy 2012, 7, 283-302. [CrossRef]

22. Rodrigue, J.P.; Notteboom, T.; Pallis, A.A. The financialization of the port and terminal industry: Revisiting risk and embeddedness. Marit. Policy Manag. Flagship J. Int. Shipp. Port Res. 2011, 38, 191-213. [CrossRef]

23. Engel, E.; Fischer, R.; Galetovic, A. The joy of flying: Efficient airport PPP contracts. Transp. Res. Part B Methodol. 2018, 114, 131-146. [CrossRef]

24. Rajaa, A.; Motawa, I.; Ogunlana, S.; Boateng, P. Prioritization of Demand Risk Factors in PPP. In Proceedings of the Infrastructure Projects Construction Research Congress: Construction in a Global Network 2014, Atlanta, Georgia, 19-21 May 2014.

25. Burke, R.; Demirag, I. Changing perceptions on PPP games: Demand risk in Irish roads. Crit. Perspect. Account. 2015, 27, 189-208. [CrossRef] 
26. EPEC. State Guarantees in PPPs: A Guide to Better Evaluation, Design, Implementation and Management; European PPP Expertise Centre: Luxemburg, 2011.

27. Roumboutsos, A.; Pantelias, A. Allocating revenue risk in transport infrastructure PPP projects: How it matters. Transp. Rev. 2015, 35, 183-203. [CrossRef]

28. Vecchi, V.; Hellowell, M.; Croce, R.; Gatti, S. Government policies to enhance access to credit for infrastructure-based PPPs: An approach to classification and appraisal. Public Money Manag. 2017, 37, 133-140. [CrossRef]

29. Soecipto, R.M.; Verhoest, K. Contract stability in European road infrastructure PPPs: How does governmental PPP support contribute to preventing contract renegotiation? Public Manag. Rev. 2018, 20, 1145-1164. [CrossRef]

30. Rouhani, O.M.; Geddes, R.R.; Do, W.; Gao, H.O.; Beheshtian, A. Revenue-risk-sharing approaches for public-private partnership provision of highway facilities. Case Stud. Transp. Policy 2018, 6, 439-448. [CrossRef]

31. Wang, Y.; Cui, P.; Liu, J. Analysis of the risk-sharing ratio in PPP projects based on government minimum revenue guarantees. Int. J. Project Manag. 2018, 36, 899-909. [CrossRef]

32. Wang, Y.; Gao, H.O.; Liu, J. Incentive game of investor speculation in PPP highway projects based on the government minimum revenue guarantee. Transp. Res. Part A Policy Pract. 2019, 125, 20-34. [CrossRef]

33. Buyukyoran, F.; Gundes, S. Optimized real options-based approach for government guarantees in PPP toll road projects. Constr. Manag. Econ. 2018, 36, 203-216. [CrossRef]

34. Available online: https://t20saudiarabia.org.sa/en/briefs/Pages/Policy-Brief.aspx?pb=TF3_PB3 (accessed on 2 October 2020).

35. Roumboutsos, A.; Farrell, S.; Liyanage, C.L.; Macário, R. Public Private Partnerships in Transport: Trends \& Theory (P3T3). Available online: www.ppptransport.eu (accessed on 30 January 2016).

36. Roumboutsos, A.; Farrell, S.; Verhoest, K. COST Action TU1001-Public Private Partnerships in Transport: Trends \& Theory: 2014 Discussion Series: Country Profiles \& Case Studies. 2014. Available online: www.ppptransport.eu (accessed on 30 January 2016).

37. OMEGA Centre Case Studies. Available online: http://www.omegacentre.bartlett.ucl.ac.uk/publications/om ega-case-studies/ (accessed on 30 January 2016).

38. Roumboutsos, A. E-BOOK: Business Models for Enhancing Funding and Enabling Financing for Infrastructure in Transport: PPP and Public Transport Infrastructure Financing Case Studies; Horizon 2020 European Commission; Department of Shipping, Trade and Transport, University of the Aegean: Mytilene, Greece, 2016; ISBN 978-618-82078-1-3.

39. Guasch, J.L. Granting and Renegotiating Infrastructure Concessions-Doing it Right; World Bank Institute Development Studies: Washington, DC, USA, 2004; p. 28816.

40. Engel, E.; Fischer, R.; Galetovic, A. Public-Private Partnerships to Revamp U.S. Infrastructure; The Brookings Institution: Washington, DC, USA, 2011.

41. Montecinos, C.J.; Saavedra, P.E. Renegotiation of Concession Contracts: Empirical Evidence for Public Transport Infrastructure in Peru; Universidad Alberto Hurtado: Santiago, Chile, 2014.

42. Voordijk, J.T.; Liyanage, C.; Temeljotov Salaj, A. Critical success factors in different stages of delivery in PPP transport infrastructure projects. In Public Private Partnerships in Transport: Trends and Theory; Roumboutsos, A., Ed.; Routledge: London, UK; Taylor \& Francis Group: New York, NY, USA, 2016; pp. 201-217.

43. Flyvbjerg, B.; Skamris Holme, M.K.; Buhl, S.L. Inaccuracy in Traffic Forecasts. Transp. Rev. 2006, $26,1-24$. [CrossRef]

44. Sharpe, A. Literature Review of Frameworks for Macro-Indicators; Centre for the Study of Living Standards: Ottawa, ON, Canada, 2004.

45. Nardo, M.; Saisana, M.; Saltelli, A.; Tarantola, S. Tools for Composite Indicators Building; European Commission: Brussels, Belgium, 2005. Available online: http://farmweb.jrc.cec.eu.int/ci/bibliography.htm (accessed on 2 October 2020).

46. OECD. Handbook on Constructing Composite Indicators: Methodology and User Guide; OECD Publishing: Paris, France, 2008.

47. Matas, A.; Raymond, J.L.; González-Savignat, M.; Ruiz, A. Predicting the Demand: Uncertainty Analysis and Prediction Models in Spain; Working Paper; Project Socio-Economic and Financial Evaluation of Transport Projects; Granted by Centro de Estudios y Experimentación de Obras Públicas (CEDEX), Ministerio de Fomento: Madrid, Spain, 2009. 
48. El Gibari, S.; Gómez, T.; Ruiz, F. Building composite indicators using multicriteria methods: A review. J. Bus. Econ. 2019, 89, 1-24. [CrossRef]

49. Nikolić, A.; Roumboutsos, A.; Ćirilović Stanković, J.; Mladenović, G. Has the latest global financial crisis changed the way road public-private partnerships are funded? A comparison of Europe and Latin America. Util. Policy 2020, 64, 101044. [CrossRef]

50. Rolstadås, A.; Schiefloe, P.M. Modelling project complexity. Int. J. Manag. Proj. Bus. 2017, 10, $295-314$. [CrossRef]

Publisher's Note: MDPI stays neutral with regard to jurisdictional claims in published maps and institutional affiliations.

(C) 2020 by the authors. Licensee MDPI, Basel, Switzerland. This article is an open access article distributed under the terms and conditions of the Creative Commons Attribution (CC BY) license (http://creativecommons.org/licenses/by/4.0/). 